\title{
NMDA Receptors Mediate Poly- and Monosynaptic Potentials in Motoneurons of Rat Embryos
}

\author{
Lea Ziskind-Conhaim \\ Department of Physiology and Center for Neuroscience, University of Wisconsin, Madison, Wisconsin 53706
}

We determined the contribution of giutamate receptor subtypes to developing excitatory synaptic transmission in isolated spinal cord of rat embryos. Using electrophysiological and morphological techniques, we studied the pattern of development of synapses between dorsal root afferents and motoneurons in lumbar spinal cords of 15- to 21-d-old rat embryos. Motoneuron dendritic fields and afferent projections onto motoneurons were identified by labeling with HRP. Afferents first entered the gray matter at Day 15 of gestation, and by Day 16 they terminated close to motoneuron dendritic trees. Afferent axons projected onto motoneuron dendritic fields at Day 17, when boutons were detected on motoneuron dendrites that were crossed by afferent axons.

To determine the time course of formation of functional sensorimotor synapses and their pharmacological properties, a dorsal root was stimulated while recording intracelIularly from segmental motoneurons. At Day 16, excitatory postsynaptic potentials (EPSPs) with long latencies, slow rates of rise, and long durations were recorded. The amplitudes of these EPSPs increased with membrane depolarization and in the absence of extracellular $\mathrm{Mg}^{2+}$. These EPSPs were blocked by D-2-amino-5-phosphonovalerate (APV) and ketamine, which are selective antagonists of $N$-methyl-Daspartate (NMDA) receptors. These findings suggest that initial synaptic transmission in embryonic motoneurons is mediated solely by NMDA receptors.

Short-latency EPSPs with fast rates of rise were first recorded in most motoneurons by Day 17. These EPSPs were composed of fast- and slow-rising potentials. The slow component was blocked by APV, while the fast component was eliminated by 6-cyano-7-nitroquinoxaline-2,3-dione and kynurenate. This indicates that the short-latency EPSPs are mediated by both NMDA and non-NMDA receptors.

Dose-response curves of motoneurons to L-glutamate, NMDA, and kainate demonstrated that motoneurons are sensitive to these agonists prior to the formation of synapses between afferents and motoneurons. Motoneuron responses to NMDA and kainate increased immediately after the onset

Received Mar. 17, 1989; revised June 15, 1989; accepted June 20, 1989.

I thank Ms. Scarlett Presley for excellent technical help; Dr. Peter Lipton for helpful discussions; Drs. Robert Conhaim, Lewis Haberly, Peter Lipton, and Robert Wickesberg for critical evaluation of the manuscript; Ms. Carol Dizack and Mr. Terry Stewart for help in illustration and photography. This work was supported in part by National Science Foundation (BNS-8305988), National Institutes of Health (NS-23808) and Research Career Development Award (NS-01314).

Correspondence should be addressed to Lea Ziskind-Conhaim, Department of Physiology and Center for Neuroscience, University of Wisconsin, 1300 University Avenue, Madison, WI 53706

Copyright (C) 1990 Society for Neuroscience 0270-6474/90/010125-11\$02.00/0 of short-latency EPSPs. Thls Increased sensitivity could be due to extracellular factors influenced by growing sensory axons or intrinsic properties of differentiating motoneurons.

L-Glutamate has been implicated as an excitatory neurotransmitter in the mammalian CNS (reviewed by Puil, 1981; Watkins and Evans, 1981; Foster and Fagg, 1984). It has been suggested as an excitatory transmitter in mammalian primary afferents based on its distribution in the spinal cord (Graham et al., 1967), its depolarizing effect on spinal motoneurons in vivo (Curtis and Watkins, 1963; McLennan and Lodge, 1979) and in vitro (MacDonald et al., 1982; Nelson et al., 1986), and its endogenous release during dorsal root stimulation (Takeuchi et al., 1983). L-Glutamate receptors can be broadly divided into 2 subtypes: $N$-methyl-D-aspartate (NMDA) and non-NMDA receptors. The first is activated by NMDA and is selectively inhibited by the competitive antagonist $\mathrm{D}$-2-amino-5-phosphonovalerate (APV) (Davies et al., 1981) and by the noncompetitive, voltage-dependent antagonists $\mathrm{Mg}^{2+}$ (Ault et al., 1980; Mayer et al., 1984; Nowak et al., 1984) and ketamine (Anis et al., 1983; MacDonald et al., 1987). Non-NMDA receptor subtypes are preferentially activated by other glutamate analogs such as kainate and quisqualate. Non-NMDA receptors are not blocked by APV and extracellular $\mathbf{M g}^{2+}$ but are blocked by quinoxalinediones, non-NMDA antagonists (Honoré et al., 1988), and kynurenate, which is a widc-spectrum antagonist of excitatory amino acids (Ganong et al., 1983; Jahr and Jessell, 1985).

It has been suggested that NMDA receptors mediate polysynaptic EPSPs in mammalian spinal cord (Lodge et al., 1978; Davies and Watkins, 1983; Polc, 1985), while non-NMDA receptors generate monosynaptic excitatory potentials (Haldeman and McLennan, 1972; Jahr and Yoshioka, 1986). Little is known, however, about the pharmacological properties of the initial sensorimotor synapses in mammalian spinal cord. Our physiological findings supported by the morphological observations have suggested that long-latency EPSPs are generated by activation of polysynaptic pathways and are present 1-2 d prior to the formation of short-latency monosynaptic connections. Dorsal root-evoked long-latency EPSPs were mediated solely by NMDA receptors, while short-latency EPSPs were evoked by activation of both non-NMDA (kainate/quisqualate) and NMDA receptors. Our obscrvation that motoneurons are sensitive to kainate prior to the formation of functional sensorimotor contacts indicates that the establishment of active sensorimotor synapses is not essential for inducing the appearance of kainate receptors. Increased sensitivity to NMDA and kainate immediately after sensorimotor synapses are formed suggests that dorsal root afferents influence the number, location, or binding affinity of glutamate receptors. 


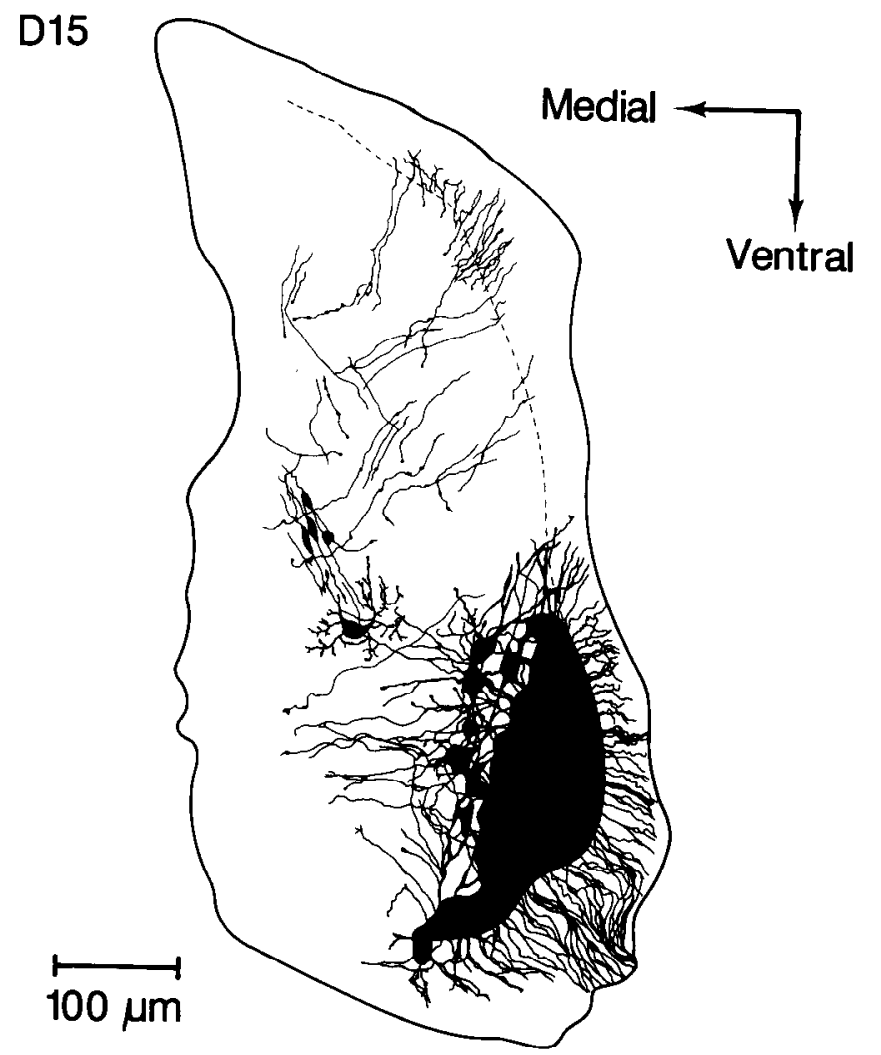

Figure 1. Camera lucida tracing of Day 15 dorsal root afferent projections and motoneurons in $\mathrm{L}_{3}$, labeled by application of HRP to the spinal roots. Afferents penetrated the gray matter and projected medially; a few afferents grew ventrally. Most afferents terminated more than $50 \mu \mathrm{m}$ away from the motoneuron dendrites, and afferent branching was not apparent. At this stage, most motoneurons were clustered in motor nuclei and their dendrites projected medially. Numerous growth cones were seen on the tips of afferents and motoneuron dendrites. One neuron with several short dendrites and growth cones on their tips can be seen at the intermediate zone. A group of 4 bipolar neurons was also present in this area.This was the only preparation in which such cells were seen. To follow the pattern of afferent projections, tracing was done from 2 successive sections $(60 \mu \mathrm{m})$. The dotted line is the border between gray and white matter.

\section{Materials and Methods}

Preparation. We used hemisected lumbar segments of spinal cord of rat embryos at Days 15-21 of gestation (birth is at 21-22 d), as described previously (Ziskind-Conhaim, 1988a). The medial surface of each cord $\left(\mathrm{L}_{2}-\mathrm{L}_{6}\right)$ was pinned to a Sylgard-coated recording chamber and maintained in recording solution for up to $9 \mathrm{hr}$. The recording solution was gassed with $95 \% \mathrm{O}_{2}-5 \% \mathrm{CO}_{2}$ and maintained at $27-29^{\circ} \mathrm{C}$. $\Lambda$ Wild microscope (M5A) was mounted on Newport vibration-free table. The recording chamber was placed on the gliding stage of the microscope, and the cord was viewed at a $50-100 x$.

$H R P$ labeling. For retrograde labeling of motoneurons and anterograde labeling of dorsal root afferent projections, the cords of Days 1321 embryos were removed and the ventral and dorsal roots of $\mathrm{L}_{3}$ or $\mathrm{L}_{4}$ were sucked into tight-fitting glass electrodes. The suction electrodes contained 30-50\% HRP (type VI, Sigma) in dissecting solution (ZiskindConhaim, 1988a). After 4-9 hr of labeling, the cords were fixed overnight at $4^{\circ} \mathrm{C}$ in $0.1 \mathrm{M}$ phosphate buffer containing $2 \%$ glutaraldehyde. They were then embedded in a gelatin-albumin mixture and immersed in a $25 \%$ sucrose solution at $4^{\circ} \mathrm{C}$. Frozen $50-70 \mu \mathrm{m}$ transverse sections were cut and processed with diaminobenzidine by the procedure of Graham and Karnovsky (1966). Cobalt and nickel were used to intensify the reaction product (Adams, 1981). The sections were counterstained with cresyl violet and reconstructed with a camera lucida (Zeiss).

Intracellular recording and stimulation. Intracellular recording and stimulation are similar to those described previously (Ziskind-Conhaim, 1988a). Motoneurons were impaled with microelectrodes (140-200 M $\Omega$ ) filled with 3 м potassium acetate. Data presented are from motoneurons with stable (more than $1 \mathrm{hr}$ ) resting membrane potentials of -55 to $-72 \mathrm{mV}(n=127)$. Motoneuron input resistance decreased from 100 $175 \mathrm{M} \Omega$ at Day 15 of gestation to $40-80 \mathrm{M} \Omega$ at Day 21 . Ventral and dorsal roots were sucked into stimulating electrodes for antidromic and orthodromic stimulation. Motoneurons were identified by antidromic potentials evoked by ventral root stimulation. EPSPs were produced by brief $(0.2-1 \mathrm{msec})$ dorsal root stimulation but because the whole root was stimulated, multiple rather than unitary EPSPs were often gencrated even at threshold stimulation for synaptic activation. Motoneurons were depolarized or hyperpolarized by currents injected intracellularly through the recording electrode (Axoprobe, Axon Instruments). Input conductance was estimated by injecting inward current $(0.05-0.2 \mathrm{nA})$ through the recording electrode while monitoring the voltage change. The signal was amplified, displayed on a digital analyzer (Data 6000, Data Precision) and recorded on a computer disk. Membrane input conductance and EPSP latency, amplitude, and rate of rise were analyzed digitally from the disk. Signals were later plotted with a multipen plotter (Hewlett-Packard).

Solutions. The recording solution contained (in $\mathrm{mM}$ ): $\mathrm{NaCl}, 116.4$; $\mathrm{KCl}, 5.4 ; \mathrm{CaCl}_{2}, 4.0 ; \mathrm{MgSO}_{4}, 1.3 ; \mathrm{NaHCO}_{3}, 26.2 ; \mathrm{NaH}_{2} \mathrm{PO}_{4}, 0.92$; glu-

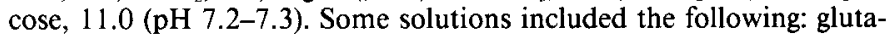
mate, NMDA, and kainate (2-2000 $\mu \mathrm{M}$; Sigma); APV $(10-100 \mu \mathrm{M}$; Cambridge Research Biochemicals and Sigma); ketamine (30-50 $\mu \mathrm{M}$; Bristol-Myers); kynurenate (0.5-4 mM, Sigma); CNQX (5-20 $\mu \mathrm{M}$; Tocris Neuramin); strychnine (10-20 $\mu \mathrm{M}$; Sigma); and picrotoxin (100-200 $\mu \mathrm{M}$; Sigma).

\section{Results}

\section{Development of dorsal root afferent projections}

The time course of development of dorsal root afferent projections and the morphological differentiation of motoneurons were determined from the HRP labeling pattern. When HRP was applied to spinal roots, motoneurons were retrogradely labeled, and afferent axons were anterogradely labeled (Ziskind-Conhaim, 1988a). At Day 13 of gestation motoneurons with short dendrites $(20-40 \mu \mathrm{m})$ were distributed medially and laterally in the intermediate and ventral horn, but their dendrites did not extend into the white matter. By Day 14, some motoneurons were clustered and their processes extended into the white matter. At this stage, dorsal root afferents penetrated into the white matter but terminated at the border between gray and white matter (Ziskind-Conhaim, 1988a). By Day 15, dorsal root afferents projected into the gray matter but did not reach the motor lateral column (Fig. 1).

Afferent projections grew ventrolaterally, and by Day 16 they terminated near motoneuron dendritic fields. Afferent axons projected into motoneuron dendritic fields at Day 17, when boutons were first detected on motoneuron dendrites (Fig. 2). These boutons were located where dorsal root afferents crossed motoneuron dendrites. Our observations suggest that synapses between afferent terminals and motoneurons form at Day 17.

We qualitatively examined the branching pattern of afferent projections as they extended toward the motor nuclei. An increase in the number of branches was evident only when afferent projections reached the motor nuclei and boutons could be seen on motoneuron dendrites (Fig. 2). The number of branches per afferent peaked at around Days 19-20 (L. Ziskind-Conhaim, unpublished observations).

\section{Development of functional synapses between dorsal root afferents and motoneurons}

To determine when functional sensorimotor synapses were formed, we recorded intracellularly from motoneurons at various developmental stages (Fig. 3). Dorsal root stimulation 


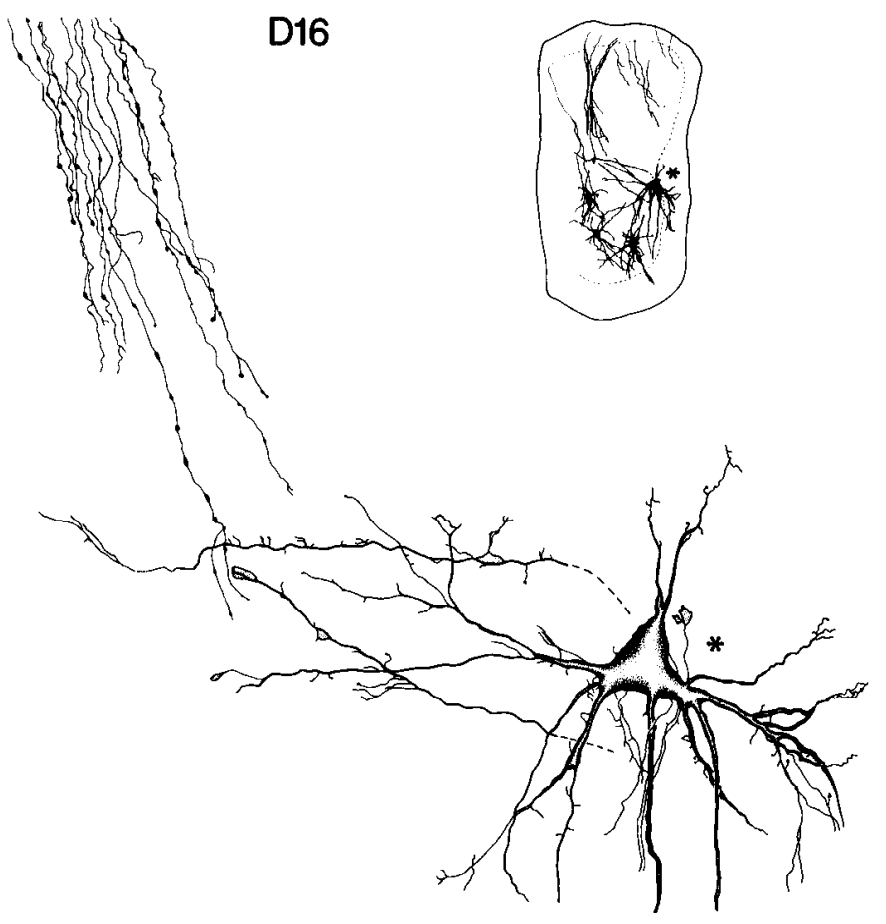

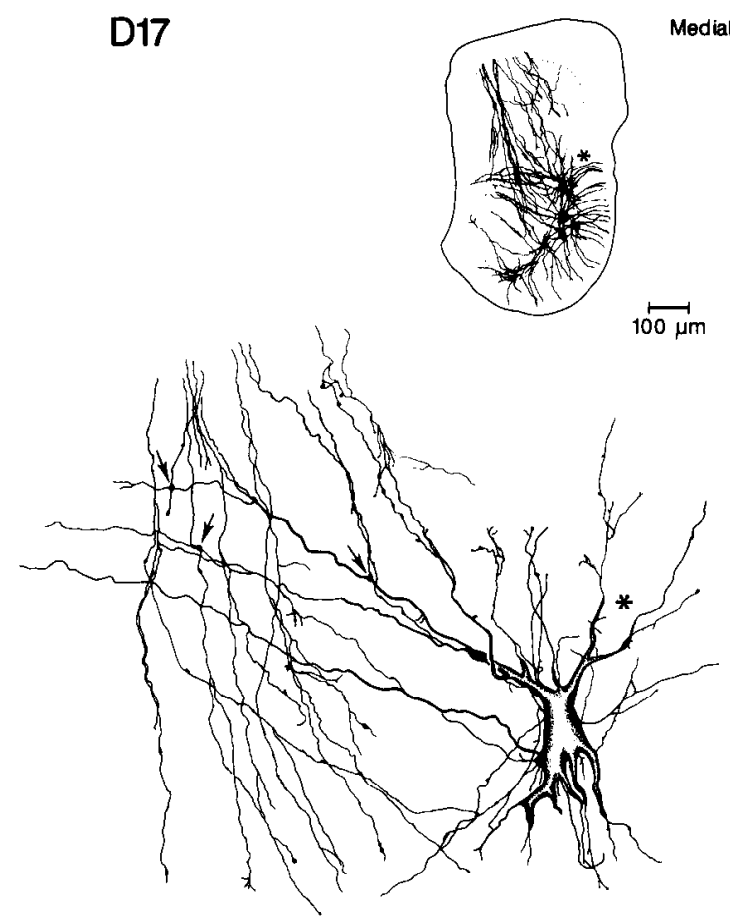

$50 \mu \mathrm{m}$

Figure 2. Drawings of afferent projections and motoneurons in $\mathrm{L}_{4}$, stained with HRP. Each drawing includes one motoneuron (asterisk) and most of the afferent axons in its proximity. These were traced at high magnification to demonstrate growth cones (gray areas) and boutons on dendrites (arrows). At Day 16 of gestation $(D 16)$, most afferents projected ventrally and terminated closer to motoneuron dendrites than at Day 15 . Some afferents crossed motoneuron dendrites, but synaptic boutons that appeared to be on the dendrites (arrows) were first seen only at Day 17 ( $D 17$ ). Afferent branching increased significantly at Day 17. Starting at Day 15 most motoneurons were clustered in motor nuclei, where it was difficult to trace individual motoneurons. Drawings of single motoneurons were therefore made from sections where individual neurons could be identified. To follow the pattern of afferent projections, processes in 2 successive sections $(60 \mu \mathrm{m})$ were drawn.

evoked long- and short-latency EPSPs that had different characteristics. The long-latency EPSPs were generated after a delay of at least $10 \mathrm{msec}$, while the short-latency EPSPs were evoked within $10 \mathrm{msec}$ after stimulation (Fig. 3). The rate of rise of the initial component of long-latency potentials (Fig. 3, D16 asterisk) varied between 0.09 to $1.1 \mathrm{mV} / \mathrm{msec}$, while a faster rate of rise was measured for the short-latency EPSPs: $0.8-4.7 \mathrm{mV}$ / msec (Fig. 3, D1 8 and D21 stars). The long-latency EPSPs were prolonged, lasting for more than $150 \mathrm{msec}$.

Long-latency compound EPSPs were recorded $1 \mathrm{~d}$ prior to the appearance of short-latency potentials. Long-latency compound EPSPs were first recorded at Day 15 in $27 \%(4 / 15)$ of motoneurons. The percentage of motoneurons with long-latency EPSPs increased to $94 \%(16 / 17)$ at Day 16 (Fig. 3) and to $100 \%$ $(n=25)$ by Day 17. Short-latency EPSPs were first recorded at Day 16 in $29 \%(5 / 17)$ of motoneurons, in $72 \%(18 / 25)$ at Day 17 , and in all motoneurons ( $n=23)$ by Day 18 .

To determine if the long-latency synaptic potentials were generated by polysynaptic pathways, we studied the effect of repetitive dorsal root stimulation on the latencies and amplitudes of EPSPs and examined the effect of anesthetics on their amplitude. In developing nerves the amplitude of the compound action potential recorded extracellularly was significantly reduced at stimulation frequency of $1 \mathrm{~Hz}$ (Ziskind-Conhaim, 1988b); therefore, dorsal root was stimulated at $\leq 0.2 \mathrm{~Hz}$. Such repetitive stimulation reduced the amplitude of the first component of long-latency EPSPs (Fig. 4, D 17 asterisk) and changed its latency and rate of rise. Repetitive stimulation did not change, however, the latency, amplitude, and rate of rise of short-latency EPSPs (Fig. 4, D20 star), suggesting that these are evoked by monosynaptic contacts.

Pentobarbital and mephenesin are more effective in attenuating poly- than monosynaptic responses because they increasc the threshold for the firing of neurons (Longo, 1961; Richens, 1969). In the presence of pentobarbital $(500 \mu \mathrm{M})$ or mephenesin ( $1 \mathrm{mM}$ ), the amplitude of long-latency EPSPs (Fig. 5, asterisks) was reduced to about $15-30 \%$ of normal values $(n=4)$, while the amplitude of the short-latency responses (Fig. 5, stars) decreased to about $60-80 \%$ of control. These results suggest that short-latency EPSPs are generated by monosynaptic contacts, while long-latency responses are mediated by excitatory interneurons.

\section{Glutamate-mediated EPSPS}

Appearance of long-latency EPSPs 1-2 d prior to the onset of short-latency EPSPs enabled us to determine the glutamate receptor subtypes responsible for the early responses. To block inhibitory postsynaptic potentials (IPSPs) that might be evoked by dorsal root stimulation, most experiments were donc in the presence of strychnine (10-20 $\mu \mathrm{M})$ and picrotoxin $(100-200 \mu \mathrm{M})$, antagonists of glycine and GABA receptors. Long-latency depolarizing IPSPs first recorded after Day 17, were completely blocked by strychnine and picrotoxin (Ziskind-Conhaim, unpublished observations).

Long-latency EPSPs. At the onset of sensory innervation, a brief dorsal root stimulation generated long-latency, prolonged 


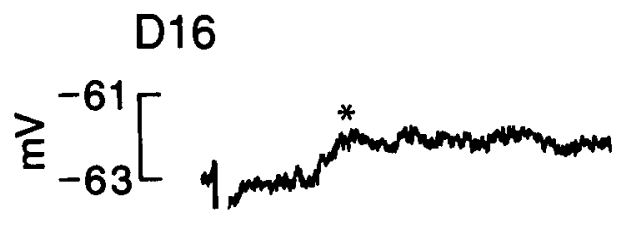

D18
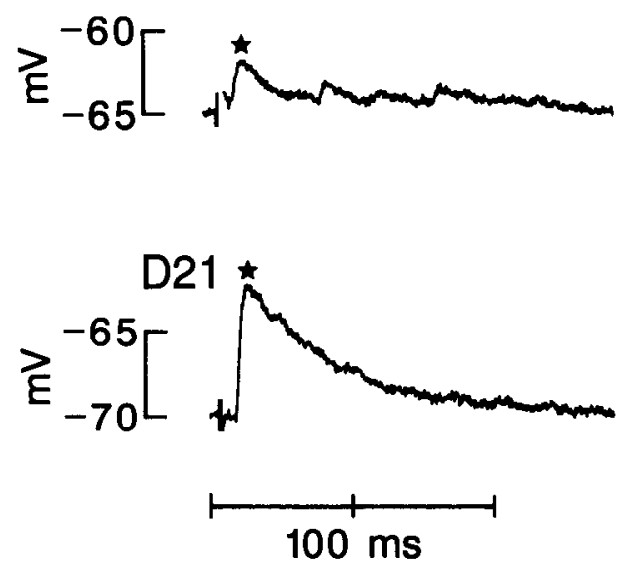

Figure 3. Excitatory synaptic potentials recorded in motoneurons at various developmental stages (Days 16-21). EPSPs were evoked by dorsal root stimulation at threshold intensity for synaptic activation. At Day 16, the latency between the stimulus artifact and the first component of EPSP (asterisk) was $30 \mathrm{msec}$, the amplitude of the initial component was $1.1 \mathrm{mV}$, and its rate of rise was $0.1 \mathrm{mV} / \mathrm{msec}$. The latency and duration of EPSPs decreased, while their amplitude and rate of rise increased between Days 16 and 18 of gestation. At Day 20, the latency of the first component (star) was $4.5 \mathrm{msec}$, its amplitude was $7.3 \mathrm{mV}$, and its rate of rise was $1.6 \mathrm{mV} / \mathrm{msec}$. EPSPs were recorded in the presence of strychnine $(10 \mu \mathrm{M})$ and picrotoxin $(100 \mu \mathrm{M})$.
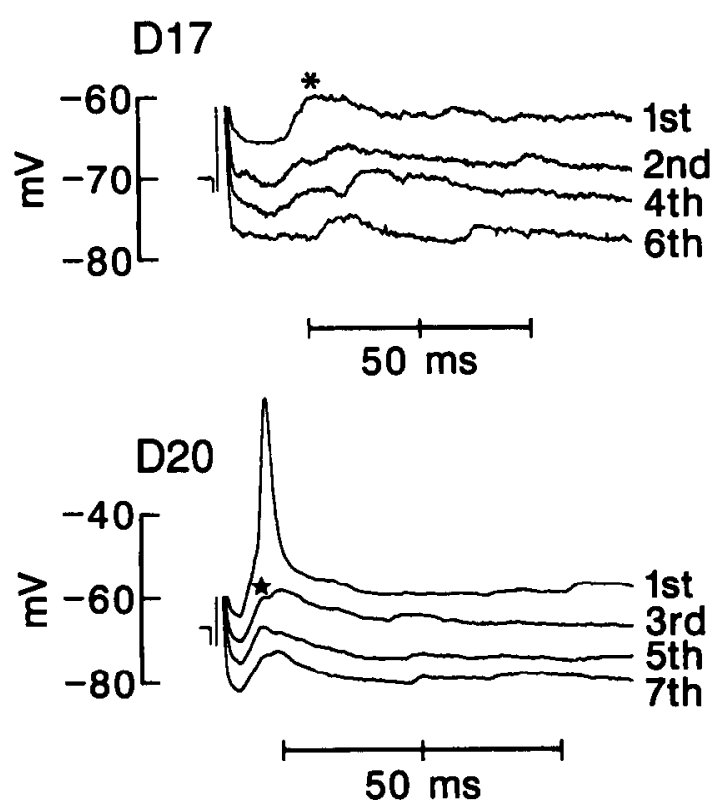

Figure 4. Effects of repetitive dorsal root stimulation on long- and short-latency afferent synaptic potentials. EPSPs were generated by repetitive stimuli at $0.2 \mathrm{~Hz}$ for $50 \mathrm{sec}$. For clarity, only 4 of the responses during such stimulus train are illustrated, as indicated by the stimulus number (to the right of the traces). At Day 17 (D17), multiple synaptic potentials with variable long-latencies were recorded. Repetitive stimulation produced a variable latency, amplitude, and rate of rise of the
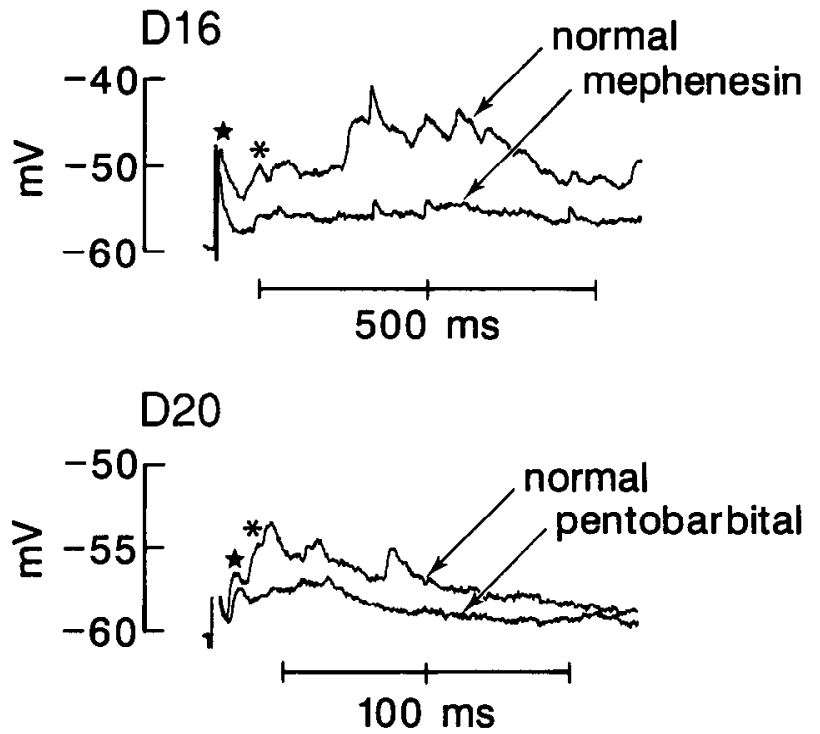

Figure 5. Actions of mephenesin $(1 \mathrm{mM})$ and pentobarbital $(500 \mu \mathrm{M})$ on long- and short-latency EPSPs recorded in spinal motoneurons at Days 16 and 20. In the presence of these drugs, the amplitude of the long-latency potentials (asterisks) was reduced more than that of the short-latency responses (stars).

EPSPs (Figs. 3-5). The amplitude of these potentials increased in the absence of extracellular $\mathrm{Mg}^{2+}$ and was significantly reduced by APV (10-20 $\mu \mathrm{M}$, Fig. 6, D16) and ketamine (30-50 $\mu \mathrm{M}$, Fig. 6, D17), selective antagonists of NMDA receptors. Ketamine is a voltage-dependent antagonist of NMDA channels; therefore, it blocked most, but not all, polysynaptic potentials. The increased amplitude in the absence of extracellular $\mathrm{Mg}^{2+}$ was probably due to elimination of $\mathrm{Mg}^{2+}$ block of NMDAactivated channels, although other mechanisms cannot be ruled out (see Discussion).

In 2 motoneurons (at Days 15 and 16), afferent EPSPs could not be detected in normal recording solution, but a prolonged large-amplitude depolarization $(>7 \mathrm{mV})$ was evoked after removal of extracellular $\mathrm{Mg}^{2+}$ (Fig. 6, D16). These prolonged potentials lasted for $0.5-2 \mathrm{sec}$ and were blocked by APV. Our results suggest that at early stages of synaptogenesis the longlatency polysynaptic EPSPs are mediated solely by NMDA receptors.

NMDA receptors that mediate polysynaptic EPSPs may be present on excitatory interneurons or motoneurons. To examine whether NMDA receptors were present on motoneurons, we studied the effects of membrane polarization on the amplitude of long-latency, slow-rising EPSPs. The amplitude of these EPSPs was voltage-dependent: Hyperpolarizing currents decreased it, while depolarizing currents increased it. Dorsal root potentials evoked at a membrane potential of $-50 \mathrm{mV}$ (mean resting potential: $-62 \mathrm{mV}, n=6$ ) often exceeded threshold and generated 1-3 action potentials (Fig. 7). The decreased amplitude during membrane hyperpolarization is characteristic of NMDAmediated EPSPs (Dingledine, 1983; Forsythe and Westbrook, 1988), and it results from removal of voltage-dependent $\mathbf{M g}^{2+}$ block of NMDA channels (Ault et al., 1980; Mayer et al., 1984;

first component of EPSPs (asterisk). At Day 20 (D20), however, the latency, amplitude, and rate of rise of the first component of EPSP (star) was relatively constant during the stimulus train. 

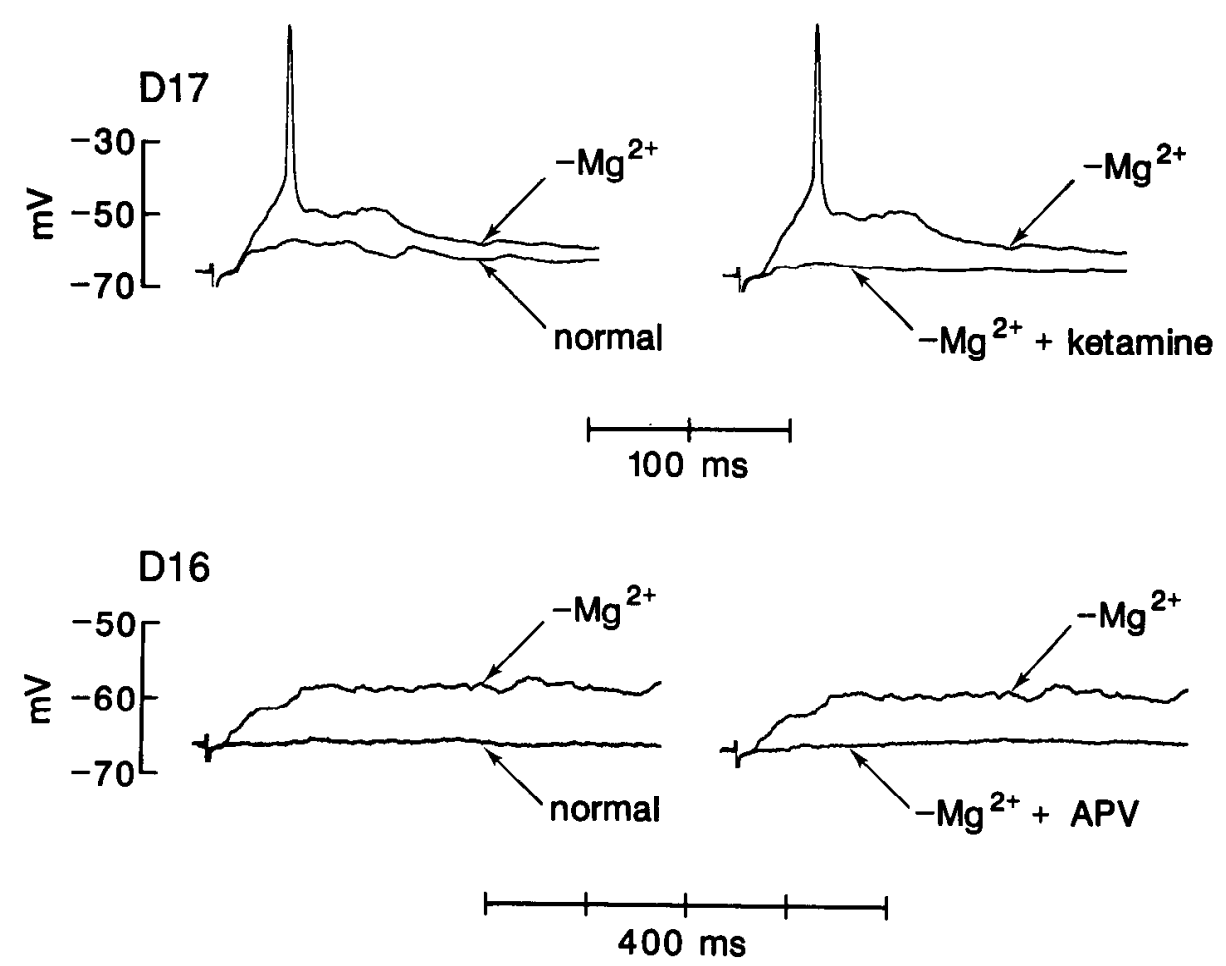

Figure 6. The amplitude of long-latency synaptic potentials increased in the absence of extracellular $\mathrm{Mg}^{2+}$ and was reduced by NMDA antagonists. At Day 17 (DI7), dorsal root stimulation evoked an action potential after removal of extracellular $\mathbf{M g}^{2+}$. The regenerative potential and most of the subthreshold EPSPs were blocked by ketamine $(50 \mu \mathrm{M})$. At Day $16(D / 6)$, high-intensity dorsal root stimulation failed to generate synaptic potentials $(>0.2 \mathrm{mV})$. After the removal of extracellular $\mathrm{Mg}^{2+}\left(-M g^{2+}\right)$, however, the same stimulus intensity produced large $(8.5 \mathrm{mV})$, prolonged synaptic depolarizations that were blocked by APV ( 20 $\mu \mathrm{M})$.
Nowak et al., 1984). These findings indicate that NMDA receptors are present on motoneurons. It is not known whether NMDA receptors are also present on excitatory intcrncurons.

Short-latency EPSPS. Short-latency EPSPs consisted of fastand slow-rising potentials. The existence of slow-rising, prolonged NMDA-mediated potentials was revealed when the synaptic response evoked in the presence of APV was subtracted from the response recorded in normal solution (Fig. $8, n=5$ ). The antagonistic action of APV on both short- and long-latency EPSPs is demonstrated in Figure 9, $A, B$. The slow-rising component of short-latency EPSP was also apparent when the fastrising component was blocked by 6-cyano-7-nitroquinoxaline2,3-dione (CNQX; 5-10 $\mu \mathrm{M}$ ), an antagonist of non-NMDA receptors (Fig. 9B). Although initially CNQX was more effective in reducing the amplitude of short-latency EPSPs, it also reduced the amplitude of long-latency potentials when it was applied at higher concentrations or when motoneurons were exposed to it for more than $7 \mathrm{~min}$ (Fig. $9 C, n=4$ ). The mechanism for CNQX-delayed block is not known. One possibility is that CNQX has a delayed effect on NMDA receptors. It is unlikely that CNQX-delayed block is on non-NMDA receptors because these are effectively blocked immediately after CNQX application (Fig. 9B). In all motoneurons $(n=9)$, kynurenate $(2-4 \mathrm{mM})$ completely eliminated the component of the synaptic potential not blocked by APV or CNQX.

To further assess the contribution of NMDA and non-NMDA receptors to short-latency EPSPs, we examined the effect of low extracellular $\mathrm{Mg}^{2+}$ on their amplitude. Removal of extracellular $\mathrm{Mg}^{2+}$ increased $(n=4)$ or did not significantly change $(n=3)$ the amplitude of short-latency EPSPs (Fig. 10). The mixed action of $\mathrm{Mg}^{2+}$ reflects the contribution of both NMDA and nonNMDA receptors to short-latency EPSPs (see Discussion). The finding that $\mathrm{Mg}^{2+}$ is not an effective voltage-sensitive antagonist of short-latency EPSPs was confirmed by changing the motoneuron membrane potential. Unlike long-latency potentials, the amplitude of short-latency EPSPs decreased with membrane depolarization and increased with hyperpolarization $(n=4)$. In 2 motoneurons, however, the amplitude of short-latency EPSPs did not change with membrane hyperpolarization (Fig. 7). Our

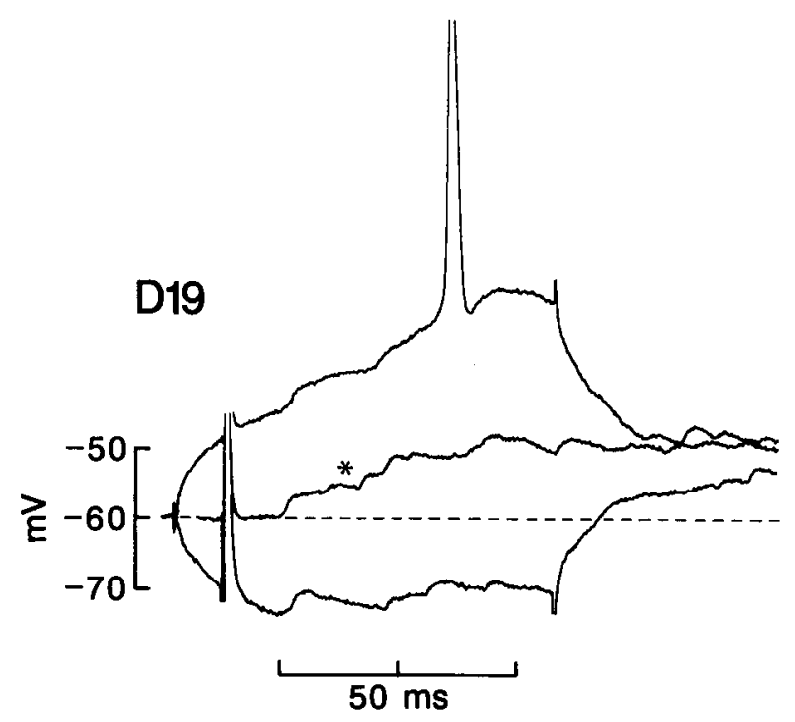

Figure 7. Effects of membrane polarization on the amplitude of longlatency EPSPs recorded in a motoneuron at Day 19 (D19). The amplitude of long-latency EPSPs (asterisk) decreased with increased hyperpolarizing currents (bottom trace) and increased with depolarizing currents. During membrane depolarization, the amplitude of EPSPs often exceeded the action potential threshold (top trace). Such membrane depolarization (to $-45 \mathrm{mV}$ ) did not generate an action potential in the absence of dorsal root stimulation. Note that the amplitude of short-latency EPSPs did not change with hyperpolarizing currents. The EPSPs shown were generated before (middle trace) and after intracellular injection of $0.15 \mathrm{nA}$ inward and outward currents. Resting potential is marked by the dashed line. 


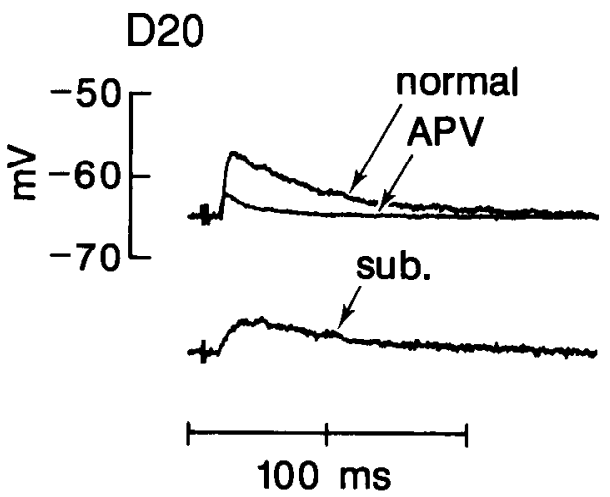

Figure 8. APV reduced the amplitude of monosynaptic EPSPs recorded in a motoneuron at Day $20($ D20). The EPSPs were generated by the same stimulus intensity (at threshold intensity for synaptic activation) before and after application of APV. Bottom trace (sub.), synaptic potential in the presence of APV $(10 \mu \mathrm{M})$ digitally subtracted from a potential evoked in normal recording solution. This trace therefore represents the NMDA-mediated synaptic potential. Kynurenate ( $2 \mathrm{~mm}$ ) eliminated the component of synaptic potential not blocked by APV (not shown). EPSPs were recorded in the presence of strychnine $(10 \mu \mathrm{M})$ and picrotoxin $(100 \mu \mathrm{M})$.

results suggest that short-latency monosynaptic EPSPs are composed of fast non-NMDA and slow NMDA-mediated potentials.

\section{Motoneuron sensitivity to L-glutamate, NMDA, and kainate}

To compare motoneuron sensitivity to L-glutamate, NMDA, and kainate, we analyzed membrane conductance and voltage changes induced by perfusing the spinal cord with these agonists. Agonist-induced conductance change was measured as the difference between the resting conductance and the maximal conductance recorded in the presence of the agonist. At all developmental stages, both NMDA and kainate induced conductance changes that were larger than those induced by glutamate. L-Glutamate produced depolarizations that were preceded by a decrease in membrane conductance at low concentrations of glutamate (50-200 $\mu \mathrm{M}, n=9)$ or a conductance increase at higher concentrations $(n=15)$. Glutamate also produced TTX-resistant spontaneous potentials. Slow desensitization of glutamateinduced conductance increase was apparent in about $80 \%$ (19/ 24) of motoneurons examined (Fig. 11).

To determine if glutamate acts as a mixed agonist activating various receptor subtypes, the effects of several antagonists were studied. Glutamate-induced depolarizations were partly blocked by APV (20-100 $\mu \mathrm{M}, n=5)$ and kynurenate (0.5-1 mM, Fig. $11, n=4$ ). At these concentrations, these antagonists did not significantly change resting membrane conductance or the threshold for action potential.

At all developmental stages, motoneuron sensitivity to L-glutamate was 10 -fold lower than to kainate and $\mathrm{Mg}^{2+}$-free NMDA. The low response to glutamate was not caused by the antagonistic effect of extracellular $\mathrm{Mg}^{2+}$ because motoneuron response to glutamate $(n=5)$ did not increase after the removal of extracellular $\mathrm{Mg}^{2+}$ (see also Mayer and Westbrook, 1985).

Application of NMDA $(2-100 \mu \mathrm{M})$ produced the following responses: (1) In normal recording solution, low concentrations of NMDA (5-20 $\mu \mathrm{M})$ induced a conductance decrease, while in the absence of extracellular $\mathrm{Mg}^{3+}$ the samc concentration produced a conductance increase in the same motoneuron (Fig. 12, $n=7$ ). The conductance increase was also recorded in the presence of $\mathrm{Mg}^{2+}$ when the NMDA concentration was higher than $20 \mu \mathrm{M}$ (also Dingledine, 1983). (2) Whether membrane conductance increased or decreased, NMDA always triggered TTXresistant spontaneous potentials (Fig. 12, arrows). (3) In the absence of extracellular $\mathbf{M g}^{2}$, desensitization to NMDA (20$50 \mu \mathrm{M}$ ) was apparent in about $50 \%$ of motoneurons (8/15). (4) NMDA-induced conductance changes and depolarizations were completely blocked by APV $(50-100 \mu \mathrm{M}, n=4)$ and kynurenate (2-4 mm, $n=3$ ).

Bath application of kainate produced a conductance increase and membrane depolarization that were blocked by kynurenate but not APV. The threshold of membrane sensitivity to kainate was similar $(5 \mu \mathrm{M})$ to that of NMDA (in the absence of extra-
Figure 9. APV and CNQX reduced the amplitude of EPSPs recorded in a motoneuron at Day 21. A short-latency, fast-rising potential and long-latency small EPSPs were recorded in the presence of $20 \mu \mathrm{M}$ APV $(A)$. Ten minutes after removal of APV, the same stimulus intensity produced a short-latency potential that exceeded the threshold for action potential, and the amplitude of long-latency synaptic potentials (wash, arrow) significantly increased. Four minutes after the application of CNQX $(10 \mu \mathrm{M})$, the amplitude and rate of rise of short-latency EPSP decreased more than the amplitude of long-latency EPSPs $(B)$. Nine minutes after CNQX application, however, both short- and long-latency EPSPs were almost completely blocked $(C)$. The effect of CNQX was reversed in normal recording solution $(D)$. The evoked potentials were generated by the same stimulus intensity (at threshold intensity for synaptic activation) and were recorded in the presence of strychnine $(10 \mu \mathrm{M})$ and picrotoxin $(100 \mu \mathrm{M})$.
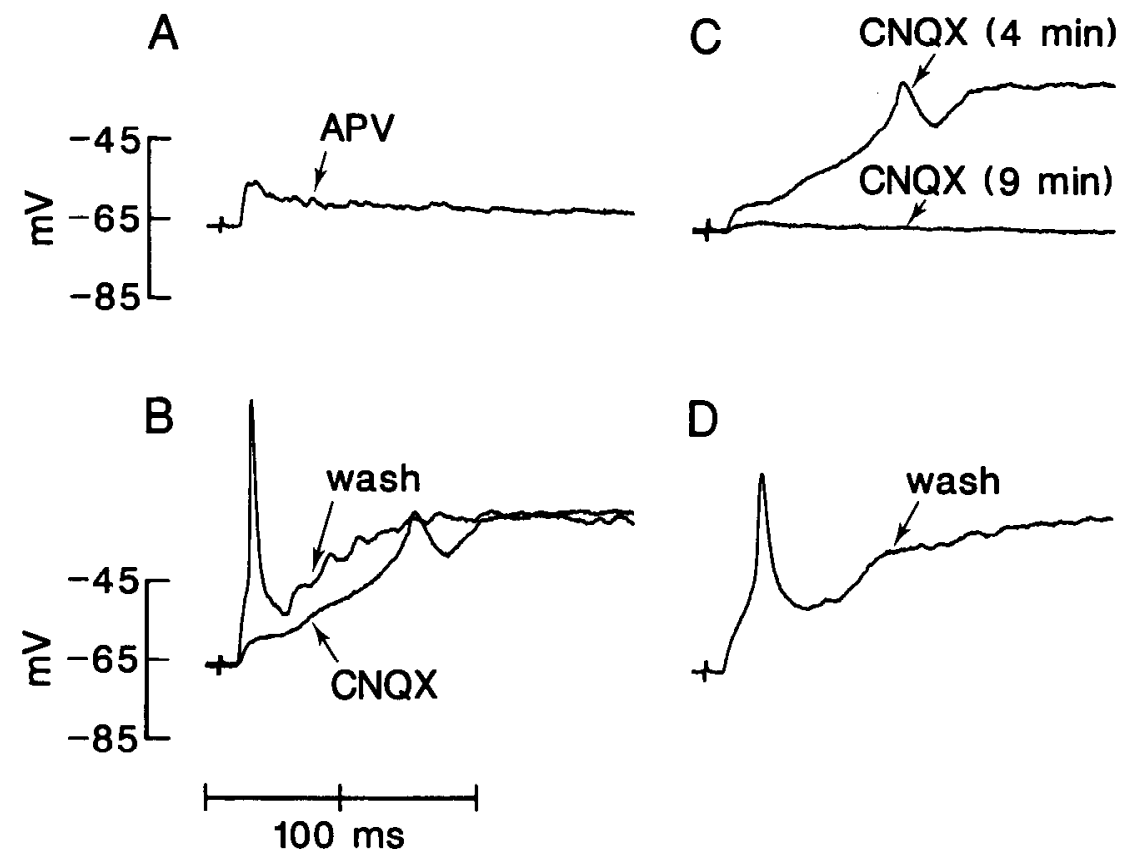

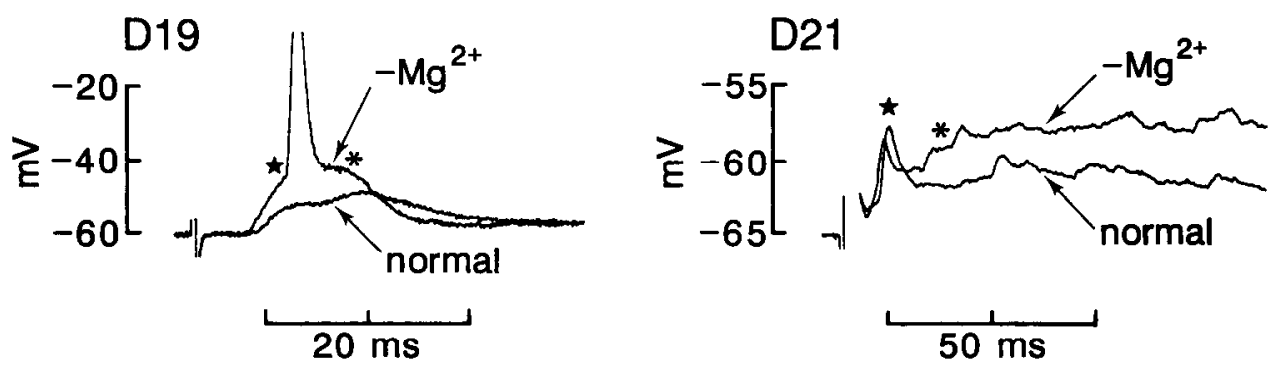

Figure 10. Effects of removal of extracellular $\mathrm{Mg}^{2+}$ on the amplitude of short- and long-latency EPSPs recorded at Days 19 and 21 . Superimposed are synaptic potentials evoked before (normal) and after the removal of $\mathrm{Mg}^{2+}\left(-\mathrm{Mg}^{2+}\right)$. In the absence of extracellular $\mathrm{Mg}^{2+}$, the latency of the short-latency EPSPs (stars) decreased, while the amplitude increased (D19) or slightly decreased $(D 2 I)$. The generation of action potential in the absence of extracellular $\mathrm{Mg}^{2+}(D 19)$ may be due to the reduction in action potential threshold. In both motoneurons the amplitude of long-latency potentials (asterisks) increased after removal of $\mathrm{Mg}^{2+}$.

cellular $\mathrm{Mg}^{2+}$ ). However, unlike NMDA, kainate always induced an increase in membrane conductance that did not densensitize. Furthermore, kainate did not generate spontaneous potentials, cven at high concentrations $(20-50 \mu \mathrm{M})$ that evoked large depolarizations (>20 mV).

To determine if motoneuron sensitivity to L-glutamate, NMDA, and kainate changes after the formation of sensorimotoneuron contacts, we compared their dose-response curves before and after the establishment of such synapses. Our results show that the conductance increase produced by NMDA and kainate increases immediately after synapse formation between dorsal root afferents and motoneurons (Fig. 13). Before monosynaptic contacts were established (Fig. 13, open symbols), 20 $\mu \mathrm{M}$ NMDA and kainate produced a conductance increase of about $4 \mathrm{nS}$, while a conductance increase of about $10 \mathrm{nS}$ was measured after the onset of short-latency EPSPs (Fig. 13). Motoneuron sensitivity to glutamate, however, seemed to decrease after the establishment of these synapses (see Discussion).

\section{Discussion}

In the spinal cord of rat embryos, long-latency EPSPs were recorded intraccllularly at Days 15-16 of gestation, 1-2 d before short-latency EPSPs were apparent. Early long-latency excitatory potentials have been demonstrated previously using extracellular recordings (Saito, 1979; Kudo and Yamada, 1985). The possibility, however, that the long-latency potentials resulted from transmission along polysynaptic pathways was not tested in those studies. Using intracellular recordings, we have demonstrated that during repetitive stimulation, the long-latency, slow-rising potentials had variable latencies and amplitudes, while the short-latency EPSPs had relatively constant latency. Furthermore, pentobarbital and mephenesin, which increase the threshold for action potential (Longo, 1961; Richens, 1969), were more effective in reducing the amplitude of long-latency EPSPs than the amplitude of short-latency EPSPs. It is unlikely that pentobarbital reduces NMDA-mediated long-latency po-

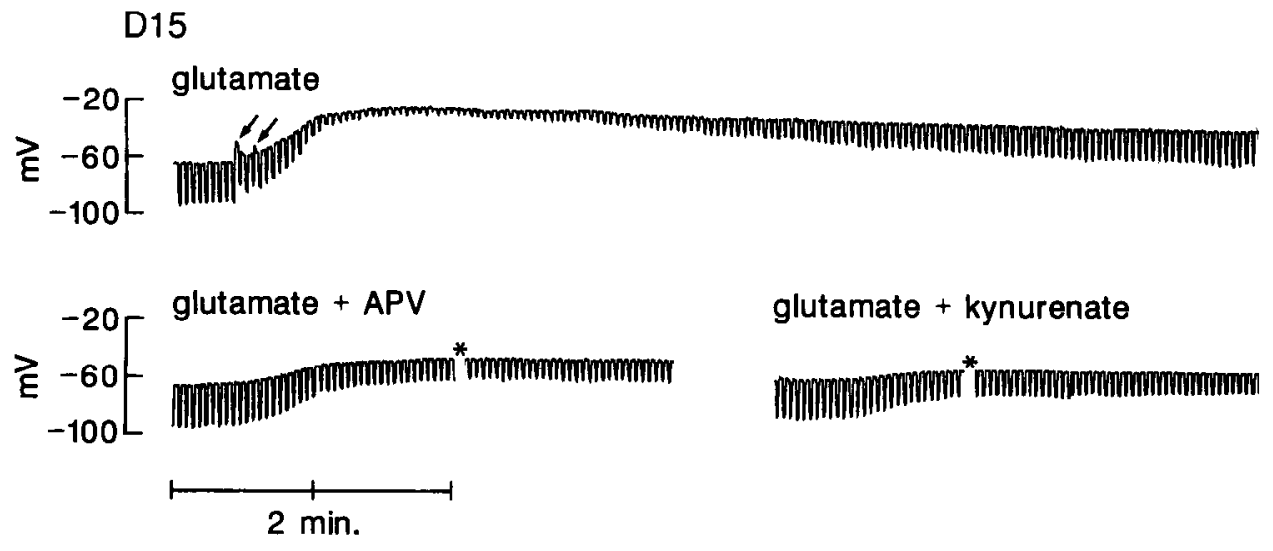

Figure 11. Responses of a motoneuron to bath application of L-glutamate and its antagonists. At Day 15 (D15), 2 mm glutamate produced a conductance increase of $34.4 \mathrm{nS}$ (from $7.2 \mathrm{nS}$ in normal solution to $41.6 \mathrm{nS}$ ) accompanied by a membrane depolarization of $34 \mathrm{mV}$. In the continuous presence of glutamate, membrane conductance decreased to $8.2 \mathrm{nS}$ and membrane potential was hyperpolarized by $20 \mathrm{mV}$. Spontaneous activity (arrows) was recorded in the presence of glutamate before the conductance increase. Spontaneous potentials were not recorded, however, when the motoneuron was desensitized. This was the largest glutamate-induced response recorded. Membrane conductance and potential returned to their resting values after removal of glutamate. In the presence of APV $(100 \mu \mathrm{M})$, glutamate $(2 \mathrm{mM})$ produced a conductance increase of $5.7 \mathrm{nS}$ and membrane depolarization of $19 \mathrm{mV}$. After $10 \mathrm{~min}$ wash in recording solution, membrane conductance and potential returned to their resting values. In the presence of kynurenate $(1 \mathrm{~mm})$, glutamate induced a conductance increase of $4.4 \mathrm{nS}$ and membrane depolarization of $6 \mathrm{mV}$. Desensitization was not apparent in the presence of these antagonists. There was a 1-2 min delay before drugs reached the preparation. The traces demonstrated here began 2 min after glutamate and its antagonists were added to the reservoir. Asterisks mark a time interval of 5 min. To estimate the membrane conductance $0.2 \mathrm{nA}$ current pulses were injected at $0.33 \mathrm{~Hz}$. 

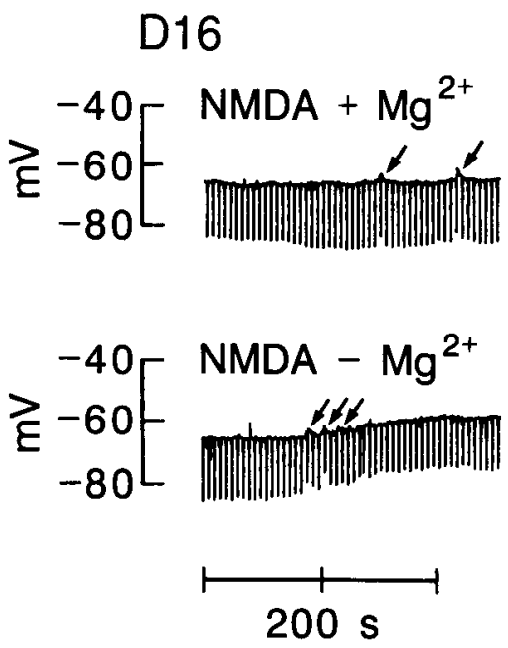

Figure 12. NMDA-induced responses in a Day $16(D 16)$ motoneuron. In normal recording solution $\left(+\mathrm{Mg}^{2+}\right), 5 \mu \mathrm{M}$ NMDA produced a conductance decrease of $1.2 \mathrm{nS}$ (resting conductance was $6.2 \mathrm{nS}$ ) and a depolarization of $2 \mathrm{mV}$. Membrane conductance and potential returned to their resting values after removal of NMDA. In the absence of extracellular $\mathrm{Mg}^{2+}\left(-\mathrm{Mg}^{2+}\right)$, membrane conductance increased by $0.9 \mathrm{nS}$ and a depolarization of $8 \mathrm{mV}$ was recorded. NMDA induced spontaneous activity in both the presence and absence of extracellular $\mathrm{Mg}^{2+}$ (arrows). To estimate membrane conductance, $0.1 \mathrm{nA}$ current pulses were injected at $0.2 \mathrm{~Hz}$.

tentials by blocking NMDA receptors/ionophores because it has been shown that pentobarbital selectively blocks kainate currents (Miljkovic and MacDonald, 1987). Our experiments suggest that long-latency EPSPs are generated by activation of polysynaptic pathways rather than by slow activation of monosynaptic connections. Moreover, the physiological data are supported by our morphological observation that at this stage (Days 15-16) dorsal root afferent projections did not reach the motor nuclei. Our studies support the suggestion that in mammals polysynaptic reflexes develop 1-2 d before the establishment of monosynaptic reflexes (Saito, 1979; Kudo and Yamada, 1987). Similar results have been observed in spinal cords of frog (Frank and Westerfield, 1983) and chick (Lee et al., 1988), suggesting that the development of excitatory sensory-interneuron-motoneuron pathways prior to sensory-motoneuron connections is characteristic of vertebrate spinal differentiation.

Many afferent projections reached the motor nuclei at Day 17, when boutons were first seen on motoneuron dendrites crossed by afferent projections. These boutons might represent synaptic contacts between dorsal root afferents and motoneuron dendrites. Electron microscopic examination at Day 17 has demonstrated that immature synapses with few synaptic vesicles and synaptic densities are indeed present in the ventral horn (Ziskind-Conhaim, unpublished observations). At this stage we found that dorsal root stimulation evoked short-latency, fastrising EPSPs in $72 \%$ of motoneurons. Our physiological and morphological observations suggest that monosynaptic contacts are established at Day 17, 1-2 d after the formation of polysynaptic contacts. It has been previously suggested that polysynaptic reflexes are first present in rat lumbar segments at Day 17, while initial monosynaptic reflexes are established at Day 19 (Kudo and Yamada, 1985). In our study we were able to record poly- and monosynaptic EPSPs in the same segments 2 $\mathrm{d}$ earlier. In the previous study, however, the peripheral nerve

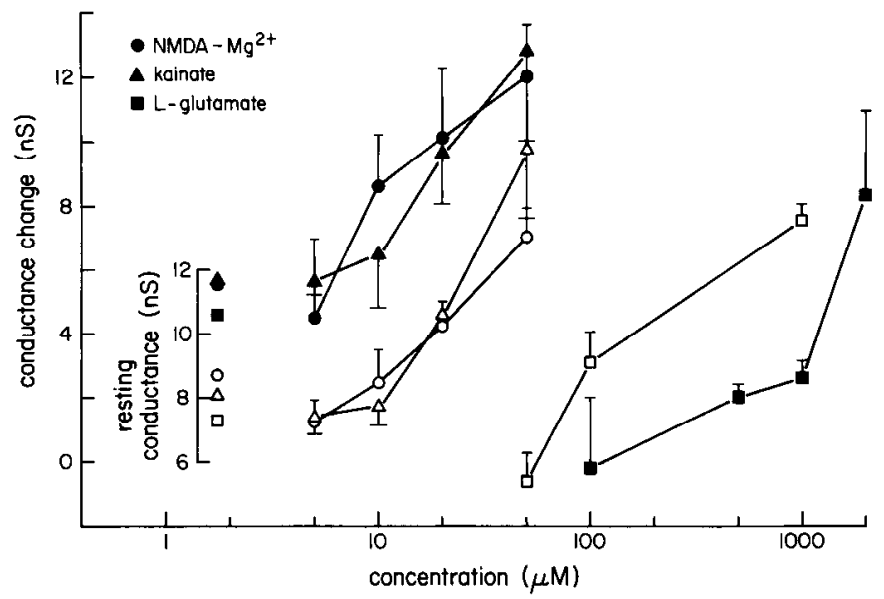

Figure 13. Dose-response curve of conductance increase as a function of concentration of L-glutamate, NMDA, and kainate. To estimate membrane conductance, small inward currents $(0.05-0.2 \mathrm{nA}$; duration, $100-400 \mathrm{msec}$; frequency, $0.2-0.4 \mathrm{~Hz}$ ) were injected intracellularly and the resultant voltages were measured (see Figs. 11 and 12). To verify the establishment of monosynaptic EPSPs, dorsal root was stimulated before agonist application. Data for motoneurons with short-latency EPSPs (filled symbols, Days 17-21) were grouped separately from those with long-latency EPSPs (open symbols, Days 15-17). The mean resting conductances are shown on the small vertical scale. Changes in membrane conductance induced by the agonists are shown on the large vertical scale. Data points: means $\pm \mathrm{SD}(n=3-6$ motoneurons). At the highest concentrations ( $50 \mu \mathrm{M}$ for NMDA and kainate, $2 \mathrm{~mm}$ for glutamate), these agonists induced depolarizations of 15-25 mV. Motoneurons that responded with larger depolarizations were not included. To rule out the possibility that glutamate and its analogs stimulated neighboring neurons and caused presynaptic activation, these experiments were conducted initially in the presence of TTX (1-2 $\mu \mathrm{M})$. In later experiments, motoneuron excitability and synaptic responses were studied in the presence of the agonists and immediately after their removal. TTX was, therefore, omitted from these recording solutions. Because the dose-response curves were identical in the presence and absence of TTX, the results of experiments with and without TTX were pooled. Some experiments were done in the presence of strychnine (10-20 $\mu \mathrm{M})$ and picrotoxin $(100-200 \mu \mathrm{M})$, although these antagonists did not affect the membrane response to the agonists studied.

was stimulated and the synaptic response was recorded extracellularly in the ventral root. It is likely that the amplitudes of synaptic potentials generated by single nerve stimulation are smaller and, therefore, would be detected later in development than EPSPs evoked by stimulating many axons in the dorsal root. In a recent report, however, Kudo and Yamada (1987) concluded that monosynaptic transmission occurs at Day 18, a day earlier than previously reported (Kudo and Yamada, 1985). This is still a day later than the short-latency EPSPs we recorded intracellularly.

Previous morphological observations have demonstrated that in thoracic and lumbar segments of rat embryos, dorsal root afferents reach the motor nuclei at Day 18 (Smith, 1983; Kudo and Yamada, 1987), $1 \mathrm{~d}$ after such connections were detected in our study. Technical variations in staining procedures and application of HRP might explain the $1 \mathrm{~d}$ difference between those studies and ours.

The number of afferent branches increased when afferents reached the motor nuclei and functional sensorimotor synapses were formed. Similar findings have been reported in chick spinal cord (Lee et al., 1988). It is possible that the onset of functional synapses between dorsal root afferents and motoneuron dendrites provides a signal for afferent branching. 
In our study, the formation of functional sensory innervation was assessed by intracellular recording and dorsal root stimulation. Stimulation of several dorsal root axons would be likely to evoke multiple EPSPs, even at threshold intensity. At the onset of sensory innervation, polysynaptic EPSPs had slower rates of rise and longer durations than monosynaptic EPSPs recorded 1-2 d later. These polysynaptic EPSPs wcre generated via excitatory interneurons and were mediated solely by NMDA receptors. Early NMDA-mediated polysynaptic EPSPs have been recorded in chick motoneurons (Lee et al., 1988), but it is not clear if NMDA receptors are present only on excitatory interneurons or on both interneurons and motoneurons. Our finding that the amplitude of polysynaptic EPSPs decreased during hyperpolarization and increased during membrane depolarization indicates that NMDA receptors are present on spinal motoneurons of rat embryos. It is not known whether NMDA receptors are also present on excitatory interneurons.

The decrease in amplitude of long-latency EPSPs during membrane hyperpolarizaton could have resulted from anomalous rectification. This is unlikely, however, because the input resistance of embryonic motoneurons is linear between -50 and $-80 \mathrm{mV}$ (Ziskind-Conhaim, unpublished observations). Furthermore, if anomalous rectification caused the decrease in amplitude of long-latency EPSPs, it should have the same effect on short-latency EPSPs. In most (4/6) motoneurons, however, the amplitude of short-latency EPSPs increased during membrane hyperpolarization.

The amplitude of NMDA-mediated potentials increases when extracellular $\mathrm{Mg}^{2+}$ is removed, probably due to elimination of $\mathrm{Mg}^{2+}$ block of NMDA-activated channels. Two other mechanisms may, however, contribute to the increased amplitude in the absence of extracellular $\mathrm{Mg}^{2+}$ : (1) a reduction in action potential threshold and (2) an increase in transmitter release. $\mathrm{Na}^{+}$ inward current increases when divalent cation concentration is markedly lowered, from 112 to $4.4 \mathrm{~mm}$ (Frankenhaeuser and Hodgkin, 1957), and transmitter release is suppressed when $\mathrm{Mg}^{2+}$ concentration is raised (Katz and Miledi, 1967). In our experiments, removal of extracellular $\mathrm{Mg}^{2+}$ reduced the threshold for action potentials evoked by intracellular current pulses by about 3-5 $\mathrm{mV}$. Such a reduction was sufficient to evoke a second action potential in $40 \%$ of motoneurons $(3 / 7)$. It is therefore possible that removal of $\mathrm{Mg}^{2+}$ increased polysynaptic transmission in some motoneurons by reducing the threshold for neuron action potentials. One reason that removal of $\mathrm{Mg}^{2+} \mathrm{did}$ not affect action potential threshold in all motoneurons may be the high concentration of divalent cations in the recording solution. High $\mathrm{Ca}^{2+}(4 \mathrm{~mm})$ has been used to improve intracellular recordings. Removal of $\mathrm{Mg}^{2+}$ alone reduced the total divalent cation concentration by $25 \%$. The high $\mathrm{Ca}^{2+} / \mathrm{Mg}^{2+}$ concentration ratio may also explain why removal of $\mathrm{Mg}^{2+}$ did not affect all monosynaptic EPSPs as might be expected from its antagonistic action on transmitter release.

It has been proposed that in mammalian spinal cord, polysynaptic transmission is mediated by NMDA receptors while non-NMDA receptors contribute mainly to monosynaptic transmission (Lodge et al., 1978; Davies and Watkins, 1983; Polc, 1985). Our experiments demonstrate, however, that NMDA-mediated potentials contribute to a slow component of monosynaptic EPSPs. Similar dual-component synaptic potentials have been recorded in developing motoneurons of Xenopus (Dale and Roberts, 1985) and in dissociated mouse spinal neurons (Forsythe and Westbrook, 1988). It has been well docu- mented that during tetanic stimulation, activation of NMDA receptors modulates synaptic transmission and produces longterm potentiation (reviewed by Nicoll et al., 1988). There is increasing evidence, however, that NMDA receptors also contribute to low-frequency synaptic transmission in a number of pathways in mammalian CNS. The contribution of NMDA receptors to synaptic potentials has been documented in hippocampus (Wigström and Gustafsson, 1984), cerebral cortex (Thomson et al., 1985), and thalamus (Salt, 1986).

There are several possible explanations for the slow-rising prolonged NMDA-mediated EPSPs. (1) L-Glutamate acts as a mixed agonist with a higher affinity for NMDA receptors. Low concentrations of glutamate in extrasynaptic regions might aclivate only NMDA receptors located away from the synaptic site. (2) NMDA channels have long open time. In dissociated mouse central neurons (Ascher and Nowak, 1988; Ascher et al., 1988) and in embryonic chick motoneurons (O'Brien and Fischbach, 1986a), the conductances and mean open times of NMDAactivated channels are larger than in non-NMDA channels.

Motoneurons are sensitive to kainate at Days 15-16, although at this stage polysynaptic transmission is mediated predominantly by NMDA receptors. The precise role of kainate receptors in monosynaptic transmission is not known because of the absence of specific antagonists that can distinguish between kainate and quisqualate receptors. Nevertheless, it is assumed that kainate receptors contribute to monosynaptic transmission (Haldeman and McLennan, 1972; Jahr and Jessell, 1985; Jahr and Yoshioka, 1986). It is possible that kainate receptors are distributed on dendrites that are not innervated by afferents of polysynaptic pathway. An alternative possibility is that prior to the establishment of synapses between afferents and motoneurons, kainate receptors are diffusely distributed at extrasynaptic regions. The newly formed synapses might then induce aggregation of kainate receptors at the synaptic site. A similar mechanism has been suggested for increased glutamate sensitivity in dissociated embryonic chick motoneurons (O'Brien and Fischbach, 1986b), and for the redistribution of $\mathrm{ACh}$ receptors on developing myotubes of rat embryos (Ziskind-Conhaim and Bennett, 1982; Ziskind-Conhaim et al., 1984).

TTX-resistant spontaneous activity was recorded in most motoneurons in the presence of NMDA and glutamate. It has been suggested that an NMDA-induced conductance decrease is sufficient to generate repetitive firing in rat hippocampal pyramidal neurons (Dingledine, 1983) and in dissociated spinal neurons (Mayer and Westbrook, 1985). The measured conductance decrease can be explained by the negative slope of the currentvoltage relationship at membrane potentials more negative than $-30 \mathrm{mV}$ (Mayer and Westbrook, 1984). In the absence of extracellular $\mathrm{Mg}^{2+}$, the negative slope is changed to a positive one, similar to that of glutamate. The effect of $\mathrm{Mg}^{2+}$ on the currentvoltage relationship can explain our observation that, in the presence of $\mathrm{Mg}^{2+}$, low concentrations of NMDA produce a conductance decrease, while a conductance increase is produced after the removal of extracellular $\mathrm{Mg}^{2+}$.

Our study demonstrates that motoneuron conductance change induced by kainate and NMDA increases immediately after the establishment of sensorimotor synapses. The increased sensitivity to kainate and NMDA might be regulated by the newly arrived afferent projections or by intrinsic changes of the differentiating motoneurons.

Motoneuron sensitivity to glutamate seems to decrease after the establishment of monosynaptic contacts. It is possible that 
the rate of desensitization of glutamate receptors (Trussell et al., 1988 ) increases during motoneuron differentiation. The recorded maximal glutamate-induced conductance increase would therefore be smaller than at earlier stages. It is also possible that development of an uptake mechanism for glutamate reduced its actual concentration in the motoneuron extracellular space. The reduction in motoneuron sensitivity to glutamate can be associated with a decrease in the number of glutamate receptors or their affinity for glutamate.

We have used electrophysiological and morphological methods to study the pattern and time course of development of sensory innervation in the spinal cord of rat embryos. We have demonstrated that long-latency, polysynaptic pathways are established 1-2 $\mathrm{d}$ before the formation of short-latency monosynaptic contacts. Pharmacological characterization of dorsal root evoked EPSPs indicates that NMDA receptors mediate both poly- and monosynaptic potentials, while the major contribution of non-NMDA receptors is to monosynaptic transmission. Establishment of sensorimotor synapses increases motoneuron sensitivity to NMDA and kainate, but the role of dorsal root afferents in inducing the increase is not clear.

\section{References}

Adams, J. C. (1981) Heavy metal intensification of DAB-based HRP reaction product. J. Histochem. Cytochem. 29: 775.

Anis, N. A., S. C. Berry, N. R. Burton, and D. Lodge (1983) The dissociative anaesthetics, ketamine and phencyclidine, selectively reduce excitation of central mammalian neurons by $N$-methyl-aspartate. Br. J. Pharmacol. 79: 565-575.

Ascher, P., and L. Nowak (1988) Quisqualate-and kainate-activated channels in mouse central neurones in culture. J. Physiol. (Lond.). 399: 227-245.

Ascher, P., P. Bregestovski, and L. Nowak (1988) N-methyl-D-aspartatc-activated channcls of mousc ccntral ncuroncs in magncsiumfree solutions. J. Physiol. (Lond.) 399: 207-226.

Ault, B., R. H. Evans, A. A. Francis, D. J. Oakes, and J. C. Watkins (1980) Selective depression of excitatory amino acid induced depolarizations by magnesium ions in isolated spinal cord preparation. J. Physiol. (Lond.) 307: 413-428.

Curtis, D. R., and J. C. Watkins (1963) Acidic amino acids with strong excitatory actions on mammalian neurones. J. Physiol. (Lond.) 166: $1-14$.

Dale, N., and A. Roberts (1985) Dual-component amino-acid-mediated synaptic potentials: Excitatory drive for swimming in Xenopus embryos. J. Physiol. (Lond.) 363: 35-59.

Davies, J., and J. C. Watkins (1983) Role of excitatory amino acid receptors in mono- and polysynaptic excitation in the cat spinal cord. Exp. Brain Res. 49: 280-290.

Davies, J., A. A. Francis, A. W. Jones, and J. C. Watkins (1981) 2 Amino-5-phosphonovalerate (2-APV), a potent and selective antagonist of amino acid-induced and synaptic excitation. Neurosci. Lett. 21: $77-81$.

Dingledine, R. (1983) N-methyl aspartate activates voltage-dependent calcium conductance in rat hippocampal pyramidal cells. J. Physiol. (Lond.) 343: 385-405.

Forsythe, I. D., and G. L. Westbrook (1988) Slow excitatory postsynaptic currents mediated by $N$-methyl-D-aspartate receptors on cultured mouse central neurones. J. Physiol. (Lond.) 396: 515-533.

Foster, A. C., and G. E. Fagg (1984) Acidic amino acid binding sites in mammalian neuronal membranes: Their characteristics and relationship to synaptic receptors. Brain Res. Rev. 7: 103-164.

Frank, E., and M. Westerficld (1983) Development of sensory-motor synapses in the spinal cord of the frog. J. Physiol. (Lond.) 343: 593610.

Frankenhaeuser, B., and A. L. Hodgkin (1957) The action of calcium on the electrical properties of squid axons. J. Physiol. (Lond.) 137: $218-244$.

Ganong, A. H., T. H. Lanthorn, and C. W. Cotman (1983) Kynurenic acid inhibits synaptic and acidic amino acid-induced responses in the rat hippocampus and spinal cord. Brain Res. 273: 170-174.
Graham, R. C., and M. J. Karnovsky. (1966) The early stages of absorption of injected horseradish peroxidase in the proximal tubules of mouse kidney: Ultrastructural cytochemistry by a new technique. J. Histochem. Cytochem. 14: 291-302.

Graham, L. T., R. P. Shank, R. Werman, and M. H. Aprison (1967) Distribution of some transmitter suspects in cat spinal cord: Glutamic acid, aspartic acid, gamma-aminobutyric acid, glycine and glutamine. J. Neurochem. 14:465-472.

Haldeman, S., and H. McLennan (1972) The antagonistic action of glutamic acid diethylester towards amino acid-induced and synaptic excitations of central neurones. Brain Res. 45: 393-400.

Honoré, T., S. N. Davies, J. Drejer, E. J. Fletcher, P. Jacobsen, D. Lodge, and F. E. Nielsen (1988) Quinoxalinediones: Potent competitive non-NMDA glutamate receptor antagonists. Science 241: $701-$ 703.

Jahr, C. E., and T. M. Jessell (1985) Synaptic transmission between dorsal root ganglion and dorsal horn neurons in culture: Antagonism of monosynaptic excitatory postsynaptic potentials and glutamate excitation by kynurenate. J. Neurosci. 5: 2281-2289.

Jahr, C. E., and K. Yoshioka (1986) Ia afferent excitation of motoneurones in the in vitro new-born rat spinal cord is selectively antagonized by kynurenate. J. Physiol. (I ond.) 370: 515-530.

Katz, B., and R. Miledi (1967) The timing of calcium action during neuromuscular transmission. J. Physiol. (Lond.) 189: 535-544.

Kudo, N., and T. Yamada (1985) Development of the monosynaptic stretch reflex in the rat: An in vitro study. J. Physiol. (Lond.) 369: 127-144.

Kudo, N., and T. Yamada (1987) Morphological and physiological studies of development of the monosynaptic reflex pathway in the rat lumbar spinal cord. J. Physiol. (Lond.) 389: 441-459.

Lee, M. T., M. J. Koebbe, and M. J. O'Donovan (1988) The development of sensorimotor synaptic connections in the lumbosacral cord of the chick embryo. J. Neurosci. 8: 2530-2543.

Lodge, D., P. M. Headley, and D. R. Curtis (1978) Selective antagonism by $\mathrm{D}$-alpha-aminoadipate of amino acid and synaptic excitation of cat spinal neurons. Brain Res. 152: 603-608.

Longo, V. G. (1961) Effects of mephenesin on the repetitive charge of spinal cord interneurones. Arch. Int. Pharmacodyn. Ther. 132: 222236.

MacDonald, J. F., A. V. Porietis, and J. M. Wojtowicz (1982) L-aspartic acid induces a region of negative slope conductance in the current-voltage relationship of cultured spinal cord neurons. Brain Res. 237: 248-253.

MacDonald, J. F., Z. Miljkovic, and P. Pennefather (1987) Use-dependent block of excitatory amino acid currents in cultured neurons by ketamine. J. Neurophysiol. 58: 251-266.

Mayer, M. L., and G. L. Westbrook (1984) Mixed-agonist action of excitatory amino acids on mouse spinal cord neurones under voltage clamp. J. Physiol. (Lond.) 354: 29-53.

Mayer, M. L., and G. L. Westbrook (1985) The action of $N$-methyl$\mathrm{D}$-aspartic acid of mouse spinal neurones in culture. J. Physiol. (Lond.) 361: 65-90.

Mayer, M. L., G. L. Westbrook, and P. B. Guthrie (1984) Voltagedependent block by $\mathrm{Mg}^{2+}$ of NMDA responses in spinal cord neurones. Nature 309: 261-263.

McLennan, H., and D. Lodge (1979) The antagonism of amino acidinduced excitation of spinal neurones in the cat. Brain Res. 169:8390.

Miljkovic, Z., and J. F. MacDonald (1987) Pentobarbital block of excitatory amino acid currents. In Excitatory Amino Acid Transmission, T. P. Hicks, D. Lodge, and H. McLennan, eds., pp. 27-34, Liss, New York.

Nelson, P. G., R. Y. K. Pun, and G. L. Westbrook (1986) Synaptic excitation in cultures of mouse spinal cord neurones: Receptor pharmacology and behaviour of synaptic currents. J. Physiol. (Lond.) 372: 169-190.

Nicoll, R. A., J. A. Kauer, and R. C. Malenka (1988) The current excitement in long-term potentiation. Neuron 1:97-103.

Nowak, L., P. Bregestovski, P. Ascher, A. Herbet, and A. Prochiantz (1984) Magnesium gates glutamate-activated channels in mouse central neurones. Nature 307: 462-465.

O'Brien, R. J., and G. D. Fischbach (1986a) Characterization of excitatory amino acid receptors expressed by embryonic chick motoneurons in vitro. J. Neurosci. 6: 3274-3283.

O'Brien, R. J., and G. D. Fischbach (1986b) Modulation of embryonic 
chick motoneuron glutamate sensitivity by interneurons and agonists. J. Neurosci. 6: 3290-3296.

Polc, P. (1985) 2-Amino-7-phosphonoheptanoic acid depresses gamma-motoneurons and polysynaptic reflexes in the cat spinal cord. Eur. J. Pharmacol. 117: 387-389.

Puil, E. (1981) S-glutamate: Its interaction with spinal neurons. Brain Res. Rev. 3: 229-322.

Richens, A. (1969) The action of general anaesthetic agents on root responses of the frog isolated spinal cord. Br. J. Pharmacol. 36: 294311.

Saito, K. (1979) Development of spinal reflexes in the rat fetus studied in vitro. J. Physiol. (Lond.) 294: 581-594.

Salt, T. E. (1986) Mediation of thalamic sensory inputs by both NMDA and non-NMDA receptors. Nature 322: 263-265.

Smith, C. L. (1983) The development and postnatal organization of primary afferent projections to the rat thoracic spinal cord. J. Comp. Neurol. 220: 29-43.

Takeuchi, A., R. Onodera, and R. Kawagoe (1983) The effect of dorsal root stimulation on the release of endogenous glutamate from the frog spinal cord. Proc. Jpn. Acad. 59: 88-92.

Thomson, A. M., C. D. West, and D. Lodge (1985) A N-methyl aspartate receptor-mediated synapse in rat cerebral cortex: A site of action of ketamine? Nature 313: 479-481.

Trussell, L. O., L. L. Thio, C. F. Zorumski, and G. D. Fischbach (1988) Rapid desensitization of glutamate receptors in vertebrate central neurons. Proc. Natl. Acad. Sci. USA 85: 4562-4566.

Watkins, J. C., and R. H. Evans (1981) Excitatory amino acid transmitters. Annu. Rev. Pharmacol. Toxicol. 21: 165-204.

Wigström, H., and B. Gustafsson (1984) A possible correlate of the postsynaptic condition for long-lasting potentiation in the guinea pig hippocampus in vitro. Neurosci. Lett. 44: 327-332.

Ziskind-Conhaim, L. (1988a) Electrical properties of motoneurons in the spinal cord of rat embryos. Dev. Biol. 128: 21-29.

Ziskind-Conhaim, L. (1988b) Physiological and morphological changes in developing peripheral nerves of rat embryos. Dev. Brain Res. 42: 15-28.

Ziskind-Conhaim, L., and J. I. Bennett (1982) The effects of electrical inactivity and denervation on the distribution of acetylcholine receptors in developing rat muscle. Dev. Biol. 90: 185-197.

Ziskind-Conhaim, L., I. Geffen, and Z. W. Hall (1984) Redistribution of acetylcholine receptors on developing rat myotubes. J. Neurosci. 4: $2346-2349$. 